\title{
The Styracaceae
}

\section{Patrícia M. Pauletti, Helder L. Teles, Dulce H.S. Silva, Ângela R. Araújo, Vanderlan S. Bolzani*}

\author{
NuBBE- Núcleo de Bioensaios, Biossintese e Ecofisiologia de Produtos Naturais, Instituto de Química, \\ Universidade Estadual Paulista, UNESP, CP 355, 14801-970, Araraquara, SP, Brazil
}

\begin{abstract}
RESUMO: "Styracaceae". Styracaceae possui 11 gêneros e aproximadamente 160 espécies, sendo árvores e arbustos, distribuídos nas regiões tropicais e subtropicais. Esta família é conhecida principalmente devido ao gênero Styrax, que é notório pela produção de um material resinoso, produto patológico, coletado a partir de incisões realizadas no caule. Esta goma é usada em perfumes, como anti-séptico, expectorante, incenso e material fumegante. Este artigo reúne os estudos fitoquímicos e biológicos realizados em 11 espécies desta família. Foram consultados 92 artigos e levantadas 130 substâncias, que indicaram que Styrax é o maior gênero desta família e o único que foi extensivamente investigado.
\end{abstract}

Unitermos: Styracaceae, Styrax, lignanas, tritepenenos, revisão.

\begin{abstract}
The Styracaceae contains 11 genera and approximately 160 species consisting of small trees and shrubs, mostly native to tropical and subtropical regions. This family is well-known by the genus Styrax, which is notorious due to the production of resinous material, a pathological product, harvested by making incisions into the tree's bark. The gum is used in perfumes, as antiseptic, expectorant, incense, and fumigating material. This paper reviews the phytochemical and biological studies carried out on 11 species of this family. A total of 92 papers were consulted, and 130 compounds were described, thus these data indicate that Styrax is by far the largest genus in the family, and the only which has been extensively investigated.
\end{abstract}

Keywords: Styracaceae, Styrax, lignans, tritepenes, review.

\section{INTRODUCTION}

The Styracaceae contains approximately 160 species grouped in 11 genera: Styrax L., Halesia J. Ellis ex L. (three species), Alniphyllum Matsum. (three species), Bruinsmia Boer. \& Koord. (two species), Huodendron Rehder (four species), Parastyrax W. W. Sm. (two species), Pterostyrax Siebold \& Zucc. (four species), Rehderodendron $\mathrm{Hu}$ (five species), Changiostyrax C. T. Chen (one specie), Melliodendron Hand. -Mazz. (one specie), and Sinojackia Hu (five species) (Fritsch et al., 2001). Traditionally, the Styracaceae has been placed with some or all of the following families: Ebenaceae, Lissocarpaceae, Sapotaceae, and Symplocaceae at the ordinal level Ebenales (Cronquist, 1981). Styrax is, by far, the largest genus in the family, consisting of about 130 species, which comprises $80 \%$ of the total number of species in Styracaceae. This genus has a widespread but disjunctive distribution, occurring in the Americas, eastern Asia, and the Mediterranean region, with over half the species presented in South America (Fritsch, 2001). Styrax distinguishes among other genera of this family due to the production of resinous material, commonly referred to as benzoin resin, usually secreted when sharp objects injure the bark. This resin has been used in many parts of the world in perfumery, cosmetics, and folk medicine as expectorant and in inhalation (Costa, 1996; Corrêa, 1926). The tincture of benzoin (a mixture of 10\% Benzoin, 2\% Aloe, 8\% Storax, 4\% Tolu Balsam and alcohol) has a long history of use and can be traced back to at least the 15 th century in the medical uses, and Egyptian and Greek times as a balsam (Lovell, 1993). It has both fungicidal and bacteriostatic properties, and it also adheres well to skin and mucous membranes (Hjorth, 1961). It has been used added to water and glycerine in preparing steam inhalations for bronchitis, asthma and other respiratory disorders (Steiner; Leifer, 1949). Allergy for tincture of Benzoin was firstly reported in 1874 with a patient who developed a purpuric eruption after inhaling its vapors. On the other hand, there have been few reports of contact allergy to Benzoin tincture suggesting that it is in fact not a strong sensitizer (Scardamaglia et al., 2003). In this review the biological activities and phytochemistry of Styrax are considered, since this genus is the only studied extensively.

\section{MATERIAL AND METHODS}


The keywords used for this review were Styracaceae, Styrax, Halesia, Alniphyllum, Bruinsmia, Huodendron, Parastyrax, Pterostyrax, Rehderodendron, Changiostyrax, Melliodendron, and Sinojackia, and the search was realized using Chemical Abstracts, Web of Science and PubMed.

\section{RESULTS AND DISCUSSION}

Consultation of the references found in our search resulted in the elaboration of a list of species studied. Table 1 and 2 describe the biological activities of crude extracts and fractions and the distribution of the compounds isolated by species, respectively. The compounds structures are presented in Figures 1-5, and the references correspond to the first report on that compound or the one in which the most relevant spectroscopic data were presented.

\section{Bioactivity of crude extracts and fractions}

The resin gum benzoin from $S$. benzoin inhibited LDL (low-density lipoproteins) oxidation lower than $2 \%$ (Teissedre; Waterhouse, 2000), and the insaponifiable fraction, obtained from the balsamic resin, showed immune stimulant activity, stimulating the phagocytic activity of reticulum endothelial system in mice inoculated with Escherichia coli (Delaveau et al., 1980).

Oral administration of dry $70 \%$ ethanolic extract from the stems of $S$. camporum Pohl, known in Brazil as "estoraque do campo" or "cuia do brejo", to rats during 15 days decreased the ulceration size, gastric secretion volume, and increased collagen fibre number of chronic ulcer induced by acetic acid. It was established that the ethyl acetate fraction was responsible for the antiulcer activity. This study supported the use of $S$. camporum hydroalcoholic extract in folk medicine as antiulcer drug (Bacchi; Sertié, 1994, Bacchi et al., 1995).

The crude extract of the leaves of $S$. ferrugineus showed antibacterial and antifungal activities against Staphylococcus aureus, Candida albicans, and Cladosporium sphaerospermum, and the MIC (minimum inhibition concentration) was established as $200 \mu \mathrm{g} / \mathrm{mL}$, $800 \mu \mathrm{g} / \mathrm{mL}$, and $750 \mu \mathrm{g}$, respectively (Pauletti et al., 2000).

The $70 \%$ aqueous acetone extract of $S$. formosanum was evaluated by various antioxidant assays, including the free radical scavenging ability using 1,1diphenyl-2-picrylhydrazyl (DPPH), hydroxyl radicals, and reducing power assays. This extract showed $\mathrm{IC}_{50}$ of $31.5 \mu \mathrm{g} / \mathrm{mL}$ and $0.3 \mu \mathrm{g} / \mathrm{mL}$ in the DPPH and hydroxyl radicals assays, respectively. The total phenolic content was determined as $2.7 \mathrm{mg}$ of gallic acid/g of dried extract determined according to a Folin-Ciocalteu method. In the reducing power assay the activity was moderated, and the results obtained in the different antioxidant assays, did not show significant correlations (Hou et al., 2003).
In Japan, pericarps of $S$. japonica found use as washing soap, cough medicine and as a piscicidal agent (Takanashi, 1991). The propan-2-one extract of $S$. japonica and the water insoluble fraction showed insecticidal action against Culex pipiens larvae (Yamaguchi et al. 1950), and the essential oil exhibited strong growth inhibitory effects on Bacillus cereus, Salmonella typhimurium and $S$. aureus (Kim; Shin, 2004; Kim et al., 2004c). The hexane and dichloromethane soluble fractions obtained from the methanolic extract of the seeds exhibited strong cytotoxic activities in brine shrimp lethality test (Kwon; Kim, 2002). A methylene chloride soluble fraction from the methanolic extract of the stem bark showed significant cell cytotoxicity in vitro by SRB method against five human tumor cell lines A549 (non small cell lungcarcinoma), SK-OV-3 (adenocarcinoma, ovary malignant ascites), SK-MEL-2 (malignant melanoma, metastasis to skin of thigh), MES-AS (uterine sarcoma), and HCT-15 (colon adenocarcinoma) (Kim et al., 2004b), and exhibited significant MMP-1 expression inhibition in vitro (Moon et al., 2005b). In addition, total saponins extract increased plasma ACTH (adrenocorticotropic hormone), corticosterone and glucose after the intraperitoneal administration in rats (Yokoyama et al., 1982).

The methanolic extract of $S$. obassia was found to inhibit production of inflammatory mediators, such as prostaglandins and leukotrienes, in vitro assay system (Jung et al., 2003).

Gummy exudates of $S$. officinalis could be applied as a suspending agent for the formulation of antiacid preparations (Shahjahan; Islan, 1998), and pericarps have been used as fish poison, furthermore it has been claimed that saponins appeared to be responsible for the ichthyotoxic action, also they were highly haemolytic (Segal et al., 1964, 1966). As well, the aqueous ethanolic extract from the aerial parts showed antitumoral activity against 3PS test systems (141\% in $10 \mathrm{mg} / \mathrm{kg}$ doses), but were toxic in high doses (Ulubelen; Gören, 1973). Proestos and coworkers studied extracts by HPLC/ UV and distinguished, identified, to quantify phenolic compounds. They also determined the antioxidant capacity with the Rancimat test using sun flower oil as substrate, and the total phenolic content in the extracts applying the Folin-Ciocalteu assay. Among the plants investigated was the leaves of $S$. officinalis that showed total phenolic concentration of $18.4 \pm 0.3 \mathrm{mg}$ of gallic $\mathrm{acid} / \mathrm{g}$ of dry extract, and the antioxidant protection factor was equal to 1.8 to the ground material and 1.7 to the methanolic extract. Additionally, the methanolic extract showed slight antimicrobial activity against E. coli, B. cereus and Pseudomonas putida, the susceptibility of the test organisms to the extract was determined by employing the standard disk diffusion technique (Proestos et al. 2006).

Essential oil from the wood of $S$. tonkinensis was investigated by disk diffusion assay and the broth dilution method against Aspergillus niger and A. flavus. It showed 
Table 1. Biological activity of crude extracts and fractions.

\begin{tabular}{lll}
\hline Species & Biological Activity & References \\
\hline S. benzoin & Antioxidant & Teissedre; Waterhouse, 2000 \\
& Immune stimulant activity & Delaveau et al., 1980 \\
\hline S. camporum & Antiulcer & Bacchi; Sertié, 1994, Bacchi et al., 1995 \\
\hline S. ferrugineus & Antibacterial and antifungal & Pauletti et al., 2000 \\
\hline S. formosanum & Antioxidant & Hou et al., 2003 \\
\hline S. japonica & Insecticidal & Yamaguchi et al., 1950 \\
& Antibacterial & Kim; Shin, 2004; Kim et al., 2004c \\
& UV protection & Moon et al., 2005b \\
& Cytotoxicity & Kwon; Kim, 2002; Kim et al., 2004b \\
& Increase: ACTH, corticosterone and glucose & Yokoyama et al., 1982 \\
& Angiotensin converting enzyme & Barbosa-Filho et al., 2006 \\
& Antiinflammatory & Jung et al., 2003 \\
\hline S. obassia & Suspending agent & Shahjahan; Islan, 1998 \\
\hline S. officinalis & Haemolytic & Segal et al., 1966 \\
& Antitumoral activity & Ulubelen; Goren, 1973 \\
& Antioxidant and antimicrobial & Proestos et al., 2006 \\
\hline S. tonkinensis & Antifungic & Shin, 2003 \\
& Immune stimulant activity & Delaveau et al., 1980 \\
\hline
\end{tabular}

relatively small inhibition zones of $4 \mathrm{~mm}$ and $5 \mathrm{~mm}$ at 25 $\mathrm{mg} /$ disk, respectively. The MIC was $0.78 \mathrm{mg} / \mathrm{mL}$ for both species of Aspergillus (Shin, 2003). Additionally, the balsamic resin and its insaponifiable fraction stimulated the phagocytic activity of reticulum endothelial system in mice inoculated with $E$. coli (Delaveau et al., 1980). The importance of this plant promoted its inclusion in Brazilian Pharmacopoeia (Brandão et al., 2006).

\section{Bioactivity of metabolites}

The saponins, jegosaponin A-D (1-4) led to complete suppression of the sensation of sweetness induced by $0.2 \mathrm{M}$ sucrose, but did not suppress the sweetness of $0.4 \mathrm{M}$ sucrose at $1 \mathrm{mM}$ solution (Yoshikawa et al., 2000).

Saponin A-B (5-6) showed fungistatic activity against Rhizoctonia solani, Pytium aphanidermatum, Rhizopus mucco, A. niger, Fusarium oxyporumlycopersici and Trichoderma viride. For the first two fungi, no mycelial growth inhibition was detected for 5 at concentrations lower than $80 \mu \mathrm{g} / \mathrm{mL}$. The dose response for $50 \%$ inhibition $\left(\mathrm{ID}_{50}\right.$ ) for $\mathbf{5}$ was determined for $T$. viride, $R$. тиссо, $F$. oxysporum, and $A$. niger as $3.4 \mu \mathrm{g} / \mathrm{mL}, 25 \mu \mathrm{g} / \mathrm{mL}, 11.7 \mu \mathrm{g} / \mathrm{mL}$, and $12 \mu \mathrm{g} /$ $\mathrm{mL}$, respectively. Saponin 6 had no fungistatic activity at lower than $80 \mu \mathrm{g} / \mathrm{mL}$ except on $T$. viride. The mechanism of action of saponins was related to their hemolytic activity (Zehavi et al., 1986; Segal et al., 1966).

Egonol (7), homoegonol (8), egonol- $\beta$ glucoside (9), homoegonol- $\beta$-glucoside (10), and dihydrodehydrodiconiferyl alcohol (11) showed antibacterial and antifungal activities against $S$. aureus and $C$. albicans with MIC in the range $10-20 \mu \mathrm{g} / \mathrm{mL}$, respectively. However, only $\mathbf{7}$ and $\mathbf{8}$ were active in the range of 5 - $10 \mu \mathrm{g}$ to $C$. sphaerospermum (Pauletti et al., 2000).

Egonol (7), homoegonol (8), and syringaresinol (12) were evaluated for their cytotoxicity by the MTT method in three cell lines: Hep-2 (larynx epidermoid carcinoma), HeLa (human cervix carcinoma) and C6 (rat glioma). Moderate activities had been observed for 7 against C6 $(10.5 \mu \mathrm{M} / \mathrm{mL})$, and Hep-2 $(11.8 \mu \mathrm{M} / \mathrm{mL})$, also for 8 against HeLa $(16.5 \mu \mathrm{M} / \mathrm{mL})$. Nevertheless, 12 was less active showing a range 27.9- $82.6 \mu \mathrm{M} / \mathrm{mL}$ (Teles et al., 2005). Additionally, the egonol derivatives attracted the attention of synthetic chemists due to its activity against human leukemic HL-60 cells (Hirano et al., 1994).

A lignan, pinoresinol (13), is useful as an antioxidant for thermoplastic resins, foods, pharmaceuticals, and cosmetics, and also as an antihypertensive (Kakie et al., 1994).

The compounds styraxlignolide B-F (14-18), taraxerol (19), syringin (20), and pinoresinol glucoside (21) were tested in vitro for antioxidant activity against DPPH. Compounds 15, 16, 17 and 21 exhibited weak radical-scavenging activity, with $\mathrm{IC}_{50}$ values of 380,278 , 194 , and $260 \mu \mathrm{M}$, respectively. In contrast, 14, 18, 19 e 20 which do not have free phenolic groups at all showed $\mathrm{IC}_{50}>500 \mu \mathrm{M}$ (Min et al., 2004a).

Compounds egonol- $\beta$-glucoside styraxjaponoside A-B (22-23), matairesinoside (24), and dihydrodehydrodiconiferyl alcohol-9'-O-glucoside (25) showed no cytotoxicity against the human dermal fibroblasts in the test dose $0.1-10 \mu \mathrm{M}$, when compared 


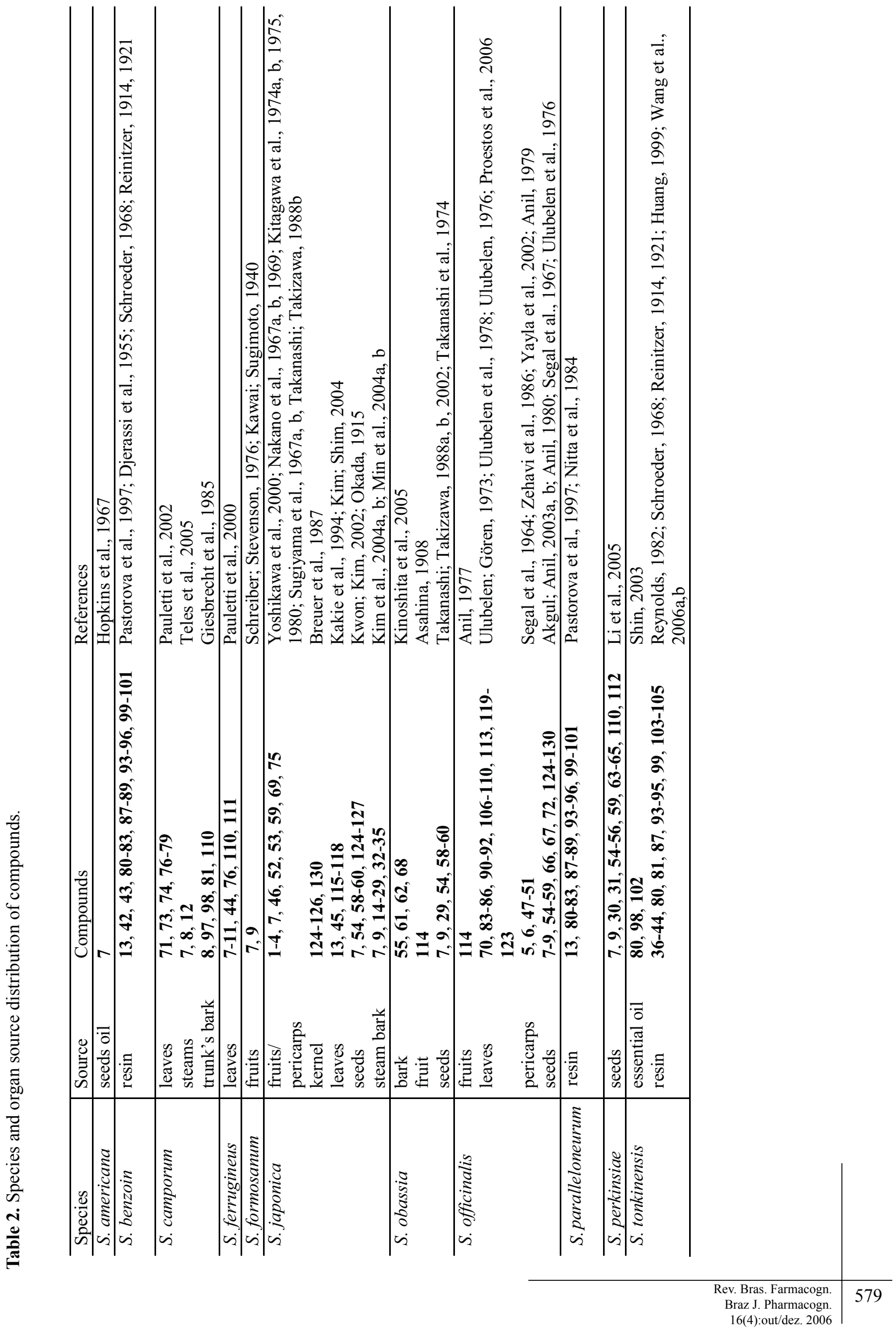


to the control. Therefore the effect of compounds on the expression of type I procollagen, and the MMP-1 proteins (matrix metalloproteinases) in cultured human dermal fibroblasts was examined, and $\mathbf{2 3}$ increased the type I procollagen protein expression level by $518.9 \pm$ $18.0 \%$, and decreased the MMP-1 protein expression level significantly by an average of $62.1 \pm 8.3 \%$ at 10 $\mu \mathrm{M}$, compared with the vehicle-treated controls cells. The UV induced MMP-1 protein expression level was significantly inhibited by $63.5 \pm 17.6 \%$, at the same concentration by a pretreatment with $\mathbf{2 3}$ in the cultured human dermal fibroblasts. Compound $\mathbf{2 3}$ exhibited almost equivalent effects on type I procolagen and MMP1 expression to that of epigallocatechin-3-gallate, which is used as a positive control. These results indicated that 23 can be used for the treatment and prevention of the skin aging processes (Kim et al., 2004a).

Compounds egonol (7), styraxlignolide A (26), styraxoside A-B (27-28), and masutakeside (29) were tested for anti-complement activity of the complement system; the modulation of complementary activity should be beneficial in the therapy of inflammatory diseases. Compounds 7, 26, 28, and 29 inhibited the hemolytic activity of the complement system with $\mathrm{IC}_{50}$ values of $33,123,65$, and $166 \mu \mathrm{M}$, respectively. In addition to, compound 27 was unable to inhibiting complement activity. The hydrolytic analogues of $\mathbf{2 6}$ and $\mathbf{2 8}$ were inactive showing that sugar moiety is necessary to enhance the anti-complementary activity of human serum against erythrocytes. On the other hand, the methylenedioxy group seems to be important to the inhibition (Min et al., 2004b).

The benzofurans 5-(3"-hydroxypropyl)-7hydroxy-2-(3',4'-methylenedioxyphenyl)benzofuran (30), and trans-5-(3"''-hydroxypropyl)-7-methoxy$2\left[2^{\prime}, 3^{\prime}\right.$-dihydro-3'-hydroxymethyl-7'-methoxy-2' (3' -methoxy-4' -hydroxyphenyl)-benzofuran-5' yl]benzofuran (31) exhibited cytotoxic activity in vitro using two breast cancer cell lines MCF-7 and MDA-MB231 (Li et al., 2005).

The triterpenes, oleanolic aldehyde acetate (32), erythrodiol-3-acetate (33), euphorginol (34), and anhydrosophoradiol-3-acetate (35) were evaluated for their cytotoxicity against tumor cells lines. Compounds 32 and 35 exhibited potent cytotoxicity against A549, SK-OV-3, SK-MEL-2, MES-AS, and HCT-15, which $\mathrm{IC}_{50}$ were in the range $5.07-9.86 \mu \mathrm{g} / \mathrm{mL}$, and $3.42-7.81$ $\mu \mathrm{g} / \mathrm{mL}$, respectively (Kim et al., 2004b). Additionally, the compounds $\mathbf{3 2}$ and $\mathbf{3 5}$ exhibited potent cytotoxicity against human dermal fibroblasts $\left(\mathrm{IC}_{50} 0.84 \mu \mathrm{M}\right.$ and 1.12 $\mu \mathrm{M}$, respectively), and compounds 33 and $\mathbf{3 4}$ did not showed cytotoxicity against human dermal fibroblasts in the test dose $0.01-1 \mu \mathrm{M}$. Thus the effect on the expression of metaloproteinases (MMP-1) and type I procollagem of $\mathbf{3 3}$ and $\mathbf{3 4}$ were examined in cultured human skin fibroblasts, given that the regulation mechanisms of MMPs activities are closely related to chronic skin diseases, such as melanona as well as photoaging, which showed higher MMP protein expression, and are caused by long term and repeated exposure of ultraviolet light. Thus 34 did not showed activity on the MMP-1 and type I procollagen synthesis, and $\mathbf{3 3}$ reduced the expression of MMP-1 but not MMP-2, at the mRNA and protein levels in a dose-dependent manner by UV irradiation, so it suggests that $\mathbf{3 3}$ plays an important role in the reduction of MMP-1 induction by UV irradiation and induced of type I procollagen (Moon et al., 2005a, b).

The triterpenoids, 3 $\beta$-hydroxy-12-oxo- $13 \mathrm{H} \alpha$ olean-28,19 $\beta$-olide (36), 6 $\beta$-hydroxy-3-oxo-11 $\alpha, 12 \alpha$ -

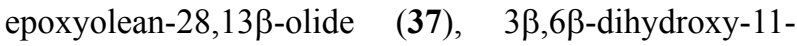
oxo-olean-12-en-28-oic acid (38), 3 $\beta, 6 \beta$-dihydroxy-

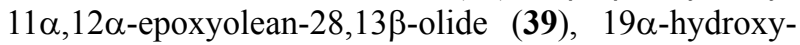
3-oxo-olean-12-en-28-oic acid (40), 6 $\beta$-hydroxy-3-oxoolean-12-en-28-oic acid (41), sumaresinolic acid (42), siaresinolic acid (43), and oleanolic acid (44) inhibited HL-60 cell growth with $\mathrm{IG}_{50}$ values ranging from 8.9 to $99.4 \mu \mathrm{M}$. Oleanolic acid (44) was the most effective antiproliferative agent, with an $\mathrm{IG}_{50}$ value of $8.9 \mu \mathrm{M}$, while (39) exhibited the least effective growth inhibition among these triterpenoids, it induced HL-60 cells to undergo differentiation as measured by an NBT reduction assay (Wang et al., 2006a).

Nerol (45) showed growth inhibitory effect in cooked rice package in the range of $0.5-1.5 \mathrm{log} \mathrm{CFU} / \mathrm{g}$, the result suggested that this compound could be used as potential agent to extend shelf life of cooked rice (Kim et al., 2004c).

\section{Phytochemistry}

Styrax has attracted considerable interest mainly due to the water insoluble resin that has been used in folk medicine and perfumery. Early works focused on the analyses of resin quality and possible adulterations. This resin, known as Benzoin gum, consists of several unique aromatic compounds. Among the resins preparation, the most important are the Siam Benzoin, which is produced from the barks of $S$. tonkinense and S. benzoin, and Sumatra Benzoin, obtained from $S$. paralleloneurum (Pastorova et al., 1997).

The phytochemistry investigation on this genus increased in 1915, when Okada isolated egonol (7) for the first time, as an unsaponifiable constituent of the seed oil of $S$. japonica and its structure was determined by Kawai and Sugiyama (Okada, 1915; Kawai; Sugiyama, 1939).

Other important classes of compounds, the saponins and sapogenin have been studied since 1899 , when Keimatsu isolated jegosaponin from the fruits of $S$. japonica. Since then, the elucidation of the chemical structure of this saponin has been the subject of a number of investigations (Asahina; Momoya, 1914a, b, Sone, 1934, 1936, Tobinaga, 1958). However, in spite of these intensive studies, no structure could be proposed for this saponin until the years 1967 and 1969 (Nakano et al., 
1967, 1969). The earlier workers (Asahina; Momoya, 1914a, b; Sone, 1934, 1936; Tobinaga, 1958) reported that the acid hydrolysis of jegosaponin yielded 2 equivalents each of glucuronic acid and glucose (Matsunami, 1927) as well as a sapogenin which, on digestion with alkali, was hydrolyzed to tiglic acid and jegosapogenol (46) (Nakano et al., 1967). Actually, the jegosaponin isolated from $S$. japonica comprises several saponins, in which, the aglycones are the acylated (acetyl, tigloyl, or 2'-cishexenoyl) derivatives of 46, and jegosapogenin is the major acid-hydrolysis product (Hayashi et al., 1967).

Besides, only one paper reported a comparative study between Styrax and Halesia. The seed, kernel or fruit oils of $S$. japonicum and $H$. carolina were analyzed for fatty acid composition, in Halesia, linoleic acid predominates over oleic acid, whereas in Styrax, equal amounts of these two acids are found (Breuer et al., 1987).

\section{CONCLUSION}

These data reveal predominately the occurrence of shikimate derivatives such as lignans derivatives of 3,7-dioxabicyclo [3.3.0], butanolide, and tetrahydrofuran, neolignans derivatives of dihydrobenzofuran, norlignans derivatives of benzofuran, phenylpropanoids, and phenolic acids, as well as the presence of acetate derivatives pentacyclic saponins and triterpenes in Styrax species. Some of saponins exhibited antisweet activity (1-4), fungistatic activity (5-6), and anti-inflammatory activity (28). The shikimate derivatives showed a variety of activities such as antibacterial and antifungal (7-11), cytotoxicity against tumor cell lines $(7,8,12,30,31)$, antioxidant activity $(\mathbf{1 3}, \mathbf{1 5}-\mathbf{1 7}, \mathbf{2 1})$ antihypertensive (13), antiinflamatory $(\mathbf{7}, \mathbf{2 6}, \mathbf{2 8}, \mathbf{2 9})$, and prevention of skin aging process $(\mathbf{2 3})$. The triterpenes showed cytotoxicity against tumor cell lines (32-44) and protection against UV irradiation (33). Our contribution was principally in relation to the isolation of pentacyclic triterpenes, and biological activity studies. Nevertheless, only some genera have been studied chemically, and the chemotaxonomic aspects of Styracaceae are far from being established. Otherwise it seems that Styrax accumulates norlignans derivatives as benzofuran, and it is important to point out that this particular class of norlignan occurs widely in Styrax. Thus benzofuran derivatives should be considered chemosystematic markers of Styrax. Additionally, it seems that Styrax being these derivatives leads chemistry. On the other hand, some extracts showed important activities and they might be useful as phytomedicines. Styrax has proven to be a very valuable genus to the discovery and utilization of medicinal natural products, and to drug discorery particularly lignans, norlignans, saponins and pentacyclic triterpenes.

\section{ACKNOWLEDGMENT}

PMP, VdaSB, HLT, and DHSS acknowledge
CNPq and FAPESP for financial support. This work was funded by grants of the State of São Paulo Research Foundation (FAPESP) within the Biota-FAPESP (www. biotasp.org.br); Grant \# 03/02176-7 awarded to Dr. Bolzani, principal investigator.

\section{REFERENCES}

Akgul YY, Anil H 2003a. Benzofuran from seeds of Styrax officinalis. Fitoterapia 74: 743-745.

Akgul YY, Anil H 2003b. Benzofurans and another constituent from seeds of Styrax officinalis. Phytochemistry 63: 939-943.

Anil H 1977. Isolation of styracitol and sucrose from fruit peels of Styrax officinalis L. Doga 1: 326-328, apud Chemical Abstracts 90:36298.

Anil H 1979. 21-Benzoyl-barringtogenol C, a sapogenin from Styrax officinalis. Phytochemistry 18: 1760-1761.

Anil H 1980. Four benzofuran glycosides from Styrax officinalis. Phytochemistry 19: 2784-2786.

Asahina Y 1908. Examination of the fruit of Styrax obassia Sieb. and Lucc. Arch Pharm 245: 325, apud Chemical Abstracts 2:8196.

Asahina Y, Momoya M 1914a. The saponin of Styrax japonica Siebold et Zuccarini. Arch Pharm 252: 56-69, apud Chemical Abstracts 8:24889.

Asahina Y, Momoya M 1914b. Saponin of Styrax japonica. J Pharm Soc Jpn 34: 105, apud Chemical Abstracts 9:5112.

Bacchi EM, Sertié JAA 1994. Antiulcer action of Styrax camporum and Caesalpinia ferrea in rats. Planta Med 60: 118-120.

Bacchi EM, Sertié JAA, Villa N, Katz H 1995. Antiulcer action and toxicity of Styrax camporum and Caesalpinia ferrea. Planta Med 61: 204-207.

Barbosa-Filho JM, Martins VKM, Rabelo LA, Moura MD, Silva MS, Cunha EVL, Souza MFV, Almeida RN, Medeiros IA 2006. Natural products inhibitors of the angiotensin converting enzyme (ACE). A review between 19802000. Rev Bras Farmacogn 16: 421-446.

Brandão MGL, Cosenza GP, Moreira RA, Monte-Mor RLM 2006. Medicinal plants and other botanical products from the Brazilian Official Pharmacopoeia. Rev Bras Farmacogn 16: 408-420.

Breuer B, Stuhlfauth T, Fock H, Huber H 1987. Fatty acids of some Cornaceae, Hydrangeaceae, Aquifoliaceae, Hamamelidaceae and Styracaceae. Phytochemistry 26: 1441-1445.

Corrêa PM 1926. Dicionário das Plantas Úteis do Brasil e das Exóticas cultivadas II. Rio de Janeiro: Ministério da Agricultura.

Costa AF 1996. Farmacognosia. Lisboa: Calouste Gulbenkian. Cronquist A 1981. An Integrated System of Classification of Flowering Plants. New York: New York Columbia University Press.

Delaveau P, Lallouette P, Tessier AM 1980. Drogues végétales stimulant l'activité phagocytaire du système réticuloendothélial. Planta Med 40: 49-54.

Djerassi C, Thomas GH, Jeger O 1955. The stereochemistry of sumaresinolic acid and its conversion to oleanolic acid. Helv Chim Acta 38: 1304-1307.

Fritsch PW, Morton CM, Chen T, Meldrum C 2001. Phylogeny 
and biogeography of the Styracaceae. Int J Plant Sci 162: S95-S116

Fritsch PW 2001. Phylogeny and biogeography of the flowering plant genus Styrax (Styracaceae) based on chloroplast DNA restriction sites and DNA sequences of the internal transcribed spacer region. Mol Phylogenet Evol 19: 387-408.

Giesbrecht AM, Alvarenga MA, Silva JJ, Panizza S 1985. Presença de homoegonol em Styrax camporum. An Farm Quim 25: 55-57.

Hayashi T, Koshiro C, Adachi T, Yosioka I, Kitagawa I 1967. Structure of jegosapogenin: 21-tigloylbarringtogenol C. Tetrahedron Lett 25: 2353-2356.

Hirano T, Gotoh M, Oka K 1994. Natural flavonoids and lignans are potent cytostatic agents against human leukemic HL-60 cells. Life Sci 55: 1061-1069.

Hjorth NH 1961. Eczematous allergy to balsams. Acta Derm Venerol 41: 1-216.

Hopkins CY, Ewing DF, Chisholm MJ 1967. Egonol. Spectrometric properties and derivatives. Can J Chem 45: 1425-1429.

Hou W-C, Lin R-D, Cheng K-T, Hung Y-T, Cho C-H, Chen C-H, Hwang S-Y, Lee M-H 2003. Free radical-scavenging activity of Taiwanese native plants. Phytomedicine 10: 170-175.

Huang KC 1999. The Pharmacology of Chinese Herbs, $2^{\text {nd }}$ ed., New York: CRC Press.

Jung H, Moon TC, Lee E, Son KH, Kim HP, Kang SS, Bae KH, An RB, Kwon DY, Chang HW 2003. Screening of arachidonic acid cascade related enzyme inhibitors from Korean indigenous Plants (2). Yakhak Hoechi 47: 69-77.

Kakie T, Harasawa A, Takase I 1994. Isolation of (+)-pinoresinol from leaf of Styrax japonica Sieb. et Zucc. Jpn Kokai Tokkyo Koho JP 9,339,833, apud Chemical Abstracts 122:27954

Kawai S, Sugiyama N 1939. Synthesis of the two egonol degradation products, dihydroconiferyl alcohol and styraxinoaldehyde. Ber 72 B, 367-380, apud Chemical Abstracts 33:37882.

Kawai S, Sugimoto K 1940. Egonol. XII. The egonol glycoside from the fruits of "taiwan-egonoki". Ber 73B: 774776, apud Chemical Abstracts 35:741

Kim M-R, Moon H-I, Chung JH, Moon YH, Hahm K-S, Woo E-R 2004a. Matrix metalloproteinase-1 inhibitor from the stem bark of Styrax japonica S. et Z. Chem Pharm Bull 52: 1466-1469.

Kim M-R, Lee H-H, Hahm K-S, Moon Y-H, Woo E-R 2004b. Pentacyclic triterpenoids and their cytotoxicity from the stem bark of Styrax japonica S. et Z. Arch Pharm Res 27: 283-286.

Kim Y-S, Oh B-C, Shin D-H 2004c. The extension of the shelf life of cooked rice by the treatment with the plant extracts and their volatile constituents. Food Sci Biotechnol 13: 519-522, apud Chemical Abstracts 142:335168.

KimY-S, Shin D-H 2004. Volatile components and antibacterial effects of simultaneous steam distillation and solvent extracts from the leaves of Styrax japonica $\mathrm{S}$. et $\mathrm{Z}$. Food Sci Biotechnol 13: 561-565, apud Chemical Abstracts 143:192660.

Kinoshita T, Haga Y, Narimatsu S 2005. New nor-neolignan glycosides from Styrax obassia (Styracaceae).
Heterocycles 65: 1471-1480.

Kitagawa I, Imakura Y, Hayashi T, Yosioka I 1974a. Structure of deacyl-jegosaponin, a common deacyl derivative of jegosaponin isolated from pericarps of Styrax japonica Sieb. et Zucc. Chem Pharm Bull 22: 1675-1677.

Kitagawa I, Imakura Y, Hayashi T, Yosioka I 1974b. Revised structure of deacyl-jegosaponin. Addendum. Chem Pharm Bull 22: 3009-3010.

Kitagawa I, Imakura Y, Hayashi T, Yosioka I 1975. Saponin and sapogenol. X. Structure of jegosapogenin and deacyljegosaponin obtained from pericarps of Styrax japonica. Chem Pharm Bull 23: 1520-1531.

Kitagawa I, Yoshikawa M, Kobayashi K, Imakura Y, Yasuhiro I, Kwang S, Ikenishi Y 1980. Saponin and sapogenol. XXVIII. Reinvestigation of the branching positions in the glucuronide moieties of the three glucuronide saponins: Deacyl-jegosaponin, deacyl-bonisaponin A, and sakuraso-saponin. Chem Pharm Bull 28: 296300 .

KwonY-K, Kim S-U 2002. Phytochemical studies on seeds of Styrax japonica Sieb. et Zucc. Agric Chem Biotechnol 45: 28-30, apud Chemical Abstracts 137:213623.

Li QL, Li BG, Qi HY, Gao XP, Zhang GL 2005. Four new benzofurans from seeds of Styrax perkinsiae. Planta Med 71: 847-851.

Lovell CR 1993. Plants and the skin. Oxford: Blackwell Scientific Publications.

Matsunami C 1927. Jegosaponin. J Pharm Soc Jpn 545: 557571, apud Chemical Abstracts 21:30064.

Min B-S, Na M-K, Oh S-R, Ahn K-S, Jeong G-S, Li G, Lee S-K, Joung H, Lee H-K 2004a. New benzofuran and butyrolactone lignans with antioxidant activity from the stem bark of Styrax japonica. J Nat Prod 67: 19801984.

Min B-S, Oh S-R, Ahn K-S, Kim J-H, Lee J, Kim D-Y, Kim E-H, Lee H-K 2004b. Anti-complement activity of norlignans and terpenes from the stem bark of Styrax japonica. Planta Med 70: 1210-1215.

Moon H-I, Seo DW, Kim K-H, Cho K-H, Eun H-C, Chung JH 2005a. Erythrodiol-3-acetate, pentacyclic triterpenoid from Styrax japonica, expressions of matrix metalloproteinase-1,2 in cultured human skin fibroblasts. J Ethnopharmacol 97: 567-571

Moon H-I, Kim M-R, Woo E-R, Chung JH 2005b. Triterpenoid from Styrax japonica Sieb. et Zucc, and its effects on the expression of matrix metalloproteinases-1 and type 1 procollagen caused by ultraviolet irradiated cultured primary human skin fibroblasts. Biol Pharm Bull 28: 2003-2006.

Nakano T, Hasegawa M 1967a. The configuration at C-21 and $\mathrm{C}-22$ in barringtogenol $\mathrm{C}$ (aescinidin), barringtogenol $\mathrm{D}$, protoaescigenin, aescigenin, and isoaescigenin. Tetrahedron Lett 17: 1675-679.

Nakano T, Hasegawa M, Fukumaru T, Tobinaga S 1967b. The structure of jegosapogenol. Tetrahedron Lett 4: 365371.

Nakano T, Hasegawa M, Fukumaru T, Durham LJ, Budzikiewicz H, Djerassi C 1969. The structure of jegosapogenol (barringtogenol $\mathrm{C}$, aescinidin) and the configuration at $\mathrm{C}-21$ and $\mathrm{C}-22$ in barringtogenol $\mathrm{D}$, aescigenin, protoaescigenin, and isoaescigenin. J Org Chem 34: 3135-3146.

Nitta A, Shohei T, Sakamaki E, Yoshinobu S 1984. On the source 
and evaluation of [gum] benzoin. $J$ Pharm Soc Jpn 104: 592-600, apud Chemical Abstracts 101:107386.

Okada H 1915. The fatty oil from the seed of Styrax japonica. J Pharm Soc Jpn 400: 657, apud Chemical Abstracts 9:2605.

Pastorova I, Koster CG, Boon JJ 1997. Analytical study of free and ester bound benzoic and cinnamic acids of gum benzoin resins by GC-MS and HPLC-frit FAB-MS. Phytochem Analysis 8: 63-73.

Pauletti PM, Araújo AR, Young MCM, Giesbrecht AM, Bolzani VS 2000. nor-Lignans from the leaves of Styrax ferrugineus (Styracaceae) with antibacterial and antifungal activity. Phytochemistry 55: 597-601.

Pauletti PM, Araujo AR, Young MCM, Bolzani VS 2002. Triterpenos de Styrax camporum (Styracaceae). Quim Nova 25: 349-352.

Proestos C, Boziaris IS, Nychas G-JE, Komaitis M 2006. Analysis of flavonoids and phenolic acids in Greek aromatic plants: Investigation of their antioxidant capacity and antimicrobial activity. Food Chem 95: 664-671

Reinitzer F 1914. Untersuchungen uber Siambenzoe. I. Verfahren zur darstellungeines neuen Krystallisier ten Bestanteils der Siambenzoe. Arch Pharm 252: 341349.

Reinitzer F 1921. Siam benzoin. II. Siaresinolic acid. Arch Pharm 259: 1-6, apud Chemical Abstracts 15:15260.

Reynolds JEF 1982. Martindale: The Extra Pharmacopoeia, 28th. ed., London: The Farmaceutical Press.

Scardamaglia L, Nixon R, Fewings J 2003. Compound tincture of benzoin: A common contact allergen? Australas $J$ Dermatol 44: 180-184.

Schreiber FG, Stevenson R 1976. Synthesis of benzofuran Styrax extratives. J Chem Soc Perkin I: 1514-1518.

Schroeder HA 1968. $p$-Hydroxycinnamyl compounds of Siam Benzoin gum. Phytochemistry 7: 57-61.

Segal R, Govrin H, Zaitschek DV 1964. A new type of saponin from Styrax officinalis L. Tetrahedron Lett 10: 527530.

Segal R, Mansour M, Zaitschek DV 1966. Effect of ester groups on the haemolytic action of some saponins and sapogenins. Biochem Pharmacol 15: 1411-1416.

Segal R, Milo-Godzweig I, Sokoloff S, Zaitschek DV 1967. A new benzofuran from the seeds of Styrax officinalis L. $J$ Chem Soc 22: 2402-2404.

Shahjahan M, Islan I 1998. Preliminary evaluation of Shilajit as a suspending agent in antiacid suspention. Drug Dev Ind Pharm 24: 1109-1112.

Shin S 2003. Anti-Aspergillus activities of plant essential oils and their combination effects with ketoconazole or amphotericin B. Arch Pharm Res 26: 389-393.

Sone C 1934. Constitution of jegosapogenin. I. Acta Phytochim 8: 23-31, apud Chemical Abstracts 29:1199.

Sone C 1936. Constitution of jegosapogenin. II. Acta Phytochim 9: 83-88, apud Chemical Abstracts 30:57119.

Steiner K, Leifer W 1949. Investigation of contact-type dermatitis due to compound tincture of benzoin. $J$ Invest Dermatol 13: 351-359.

Sugiyama N, Aoyama H, Sayama T, Yamada K 1967a. The structure of jegosapogenol. A and B. J Chem Soc Jpn 88: 1316-1319, apud Chemical Abstracts 69:27555.

Sugiyama N, Yamada K Aoyama H, Sayama T 1967b. The structures of jegosapogenol A and B. J Chem Soc Jpn
88: 794-795, apud Chemical Abstracts 69:10577.

Takanashi H 1991. The Encyclopedia of Trees. Tokyo: Hokuryukan.

Takanashi M, Takizawa Y, Mitsuhashi T 1974. 5-(3"hydroxypropyl)-2-(3',4'-methylenedioxyphenyl) benzofuran: A new benzofuran from Styrax obassia Sieb. et. Zucc. Chem Lett 8: 869-871.

Takanashi M, Takizawa Y 1988a. New benzofurans related to egonol from immature seeds of Styrax obassia. Phytochemistry 27: 1224-1226.

Takanashi M, Takizawa Y 1988b. Benzofuran compositions of unsaponifiables of Styrax japonica Sieb. et Zucc. Yukagaku 37: 1162-1164, apud Chemical Abstracts 110:111789.

Takanashi M, Takizawa Y 2002. New egonol glycoside having D-xylose from immature seeds of Styrax obassia Sieb. et Zucc. J Oleo Sci 51: 423-426.

Teissedre PL, Waterhouse AL 2000. Inhibition of oxidation of human low-density lipoproteins by phenolic substances in different essential oils varieties. J Agric Food Chem 48: 3801-3805.

Teles HL, Hemerly JP, Pauletti PM, Pandolfi JRC, Araújo AR, Valentini SR, Young MCM, Bolzani VS, Silva DHS 2005. Cytotoxic lignans from the stems of Styrax camporum (Styracaceae). Nat Prod Res 19: 319-323.

Tobinaga S 1958. Triterpenoids. X. Constitution of jegosapogenol. 1. Derivatives and selenium dehydrogenation products. J Pharm Soc Jpn 78: 526529, apud Chemical Abstracts 52:77153.

Ulubelen A, Gören N 1973. Preliminary investigations on the herba of Styrax officinalis. Planta Med 24: 290-293.

Ulubelen A 1976. $\Delta^{7}$-Stigmasteryl-3- $\beta$-D-glucoside from Styrax officinalis. Planta Med 30: 221-222.

Ulubelen A, Tanker M, Baykut F, Kar F 1976. A study with the seed oil of Styrax officinalis. Part III. Chim Acta Turc 4: 53, apud Chemical Abstracts 85:166557.

Ulubelen A, Saiki Y, Lotter H, Cari VM, Wagner H 1978. Chemical components of Styrax officinalis L. The structure of a new lignan Styraxin. Planta Med 34: 403-407.

Wang F, Hua HM, Bian X, Pei YH, Chen D, Jing YK 2006a. Triterpenoids from the resin of Styrax tonkinensis and their antiproliferative and differentiation effects in human leukemia HL-60 cells. J Nat Prod 69: 807810.

Wang F, Hua HM, Bian X, Pei YH, Jing YK 2006b. Two new aromatic compounds from the resin of Styrax tonkinensis (Pier.) Craib. J Asian Nat Prod Res 8: 137141.

Yamaguchi K, Suzuki T, Katayama A, Sasa M, Iida S 1950. Insecticidal action of japanese plants. II. A general method of detecting effective fractions and its application to 24 species of insecticidal plants. Sci Insect Control 15: 62-70, apud Chemical Abstracts 44:10245h.

Yayla Y, Alankuş-Çaliş̧an Ö, Anil H, Bates RB, Stessman CC, Kane VV 2002. Saponins from Styrax officinalis. Fitoterapia 73: 320-326.

Yokoyama H, Hiai S, Oura H, Hayashi T 1982. Effects of total saponins extracted from several crude drugs on rat adrenocortical hormone secretion. J Pharm Soc Jpn 102: 555-559.

Yoshikawa K, Hirai H, Tanaka M, Arihara S 2000. Antisweet 
natural products from Styrax japonina Sieb. et Zucc. Structures of Jegosaponins A-D. Chem Pharm Bull 48: 1093-1096.

Zehavi U, Levy M, Segal R 1986. Fungistatic activity of saponin A from Styrax officinalis L. on plant pathogens. $J$ Phytopathol 116: 338-343. 


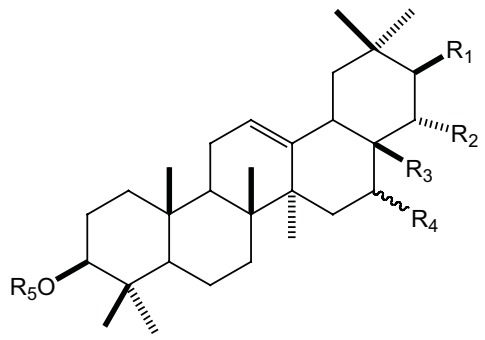

(1) Jegosaponin A

(2) Jegosaponin B

(3) Jegosaponin C

(4) Jegosaponin D

(5) Saponin A

(6) Saponin B

(28) Styraxoside B
$\begin{array}{llll}\mathbf{R}_{1} & \mathbf{R}_{2} & \mathbf{R}_{3} & \mathbf{R}_{\mathbf{4}}\end{array}$<smiles>CC/C=C(\C)C(=O)O</smiles>

$\mathrm{OAc} \quad \mathrm{CH}_{2} \mathrm{OH}$

$\alpha-\mathrm{OH}$<smiles>C/C=C(\C)C(=O)O</smiles>

$\mathrm{OH}$

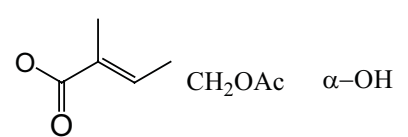<smiles>CCC/C=C\C(=O)O</smiles>

$\mathrm{OH}$

$\mathrm{CH}_{2} \mathrm{OAc} \quad \alpha-\mathrm{OH}$

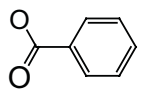

$\mathrm{OH}$

$\mathrm{CH}_{2} \mathrm{O}$

$\alpha-\mathrm{OH}$

Glycosyl moiety

$\mathrm{OH}$

$\mathrm{OH}$

$\mathrm{CH}_{2} \mathrm{O}$

$\alpha-\mathrm{OH}$

Glycosyl moiety

(46) Jegosapogenol, Barringtogenol $\mathrm{C}, \quad \mathrm{OH}$

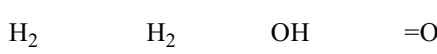

$\mathrm{OH} \quad \mathrm{CH}_{2} \mathrm{OH} \quad \alpha-\mathrm{OH}$<smiles>C/C=C(\C)C(=O)O</smiles>

OAc $\quad \mathrm{CH}_{2} \mathrm{OH} \quad \alpha-\mathrm{OH}$

(47) Styrax-saponin A

(48) Styrax-saponin B<smiles>O=C(O)c1ccccc1</smiles>

$\mathrm{OAc} \quad \mathrm{CH}_{2} \mathrm{OH} \quad \alpha-\mathrm{OH}$<smiles>CCC/C=C/C(=O)O</smiles>

$\mathrm{OH}$

$\mathrm{CH}_{2} \mathrm{OH}$

$\alpha-\mathrm{OH}$

$\mathrm{OH} \quad \mathrm{CH}_{2} \mathrm{OH} \quad \alpha-\mathrm{OH}$

$\mathrm{OH} \quad \mathrm{CH}_{2} \mathrm{OH} \quad \alpha-\mathrm{OH}$
(52) 21-Tigloyl-barringtogenol C<smiles>C/C=C(\C)C(=O)O</smiles>

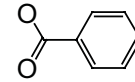

(53) Deacyl-jegosaponin
$\mathrm{OH}$

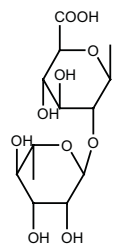

$\mathrm{H}$

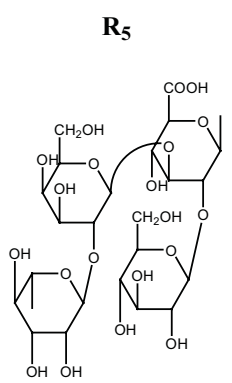

Ref

Yoshikawa et al., 2000

Yoshikawa et al., 2000

Yoshikawa et al., 2000

Yoshikawa et al., 2000

Segal et al., 1964; Zehavi et al., 1986

Segal et al., 1964; Zehavi et al., 1986

Min et al., 2004b

Nakano et al., 1967a, b, 1969

Yayla et al., 2002

Yayla et al., 2002

Yayla et al., 2002

Yayla et al., 2002

Anil, 1979

Hayashi et al., 1967

Kitagawa et al., 1974a, b, 1975, 1980

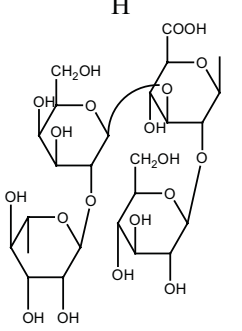

Figure 1. Saponins from Styrax species 


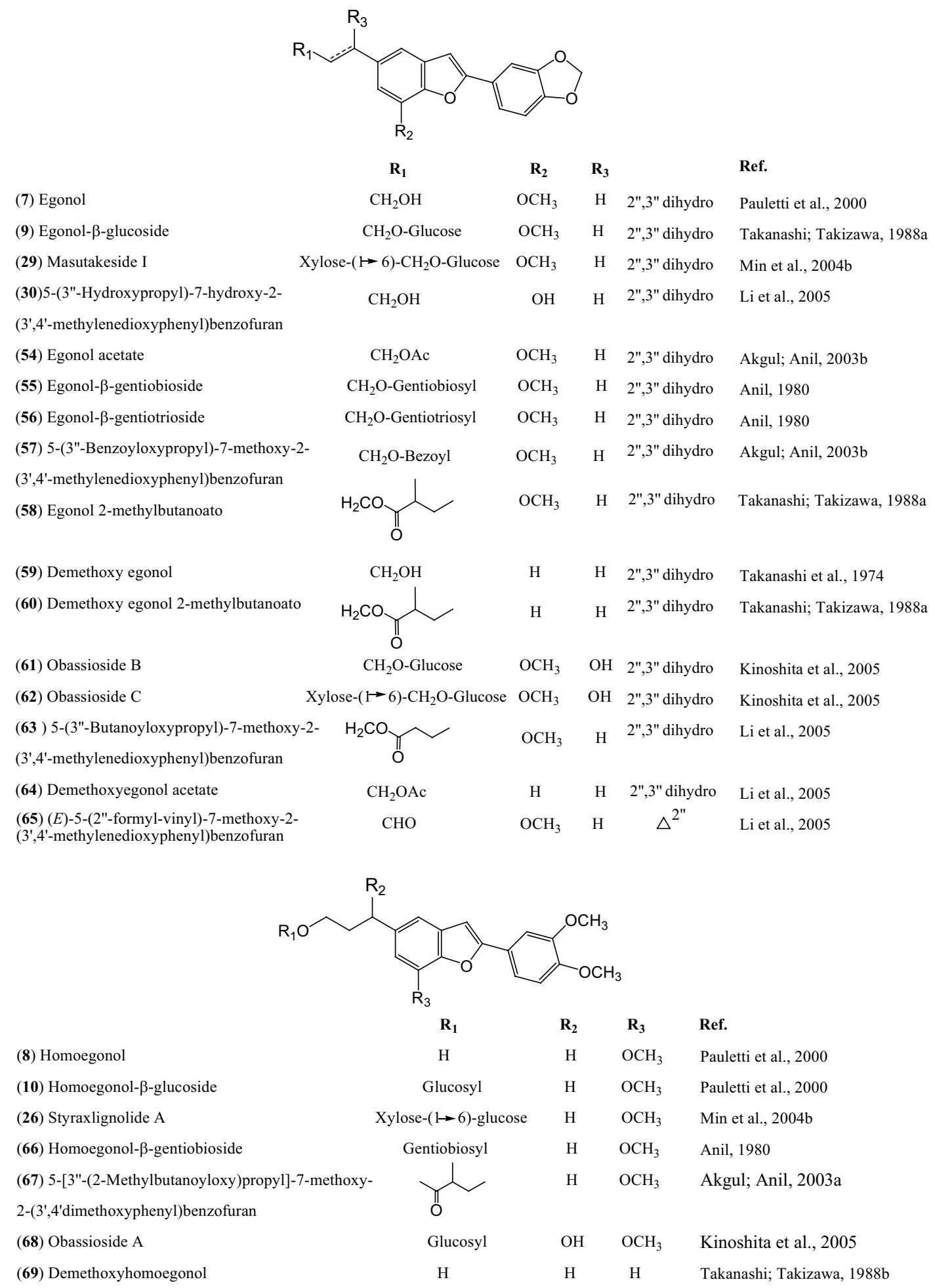

Figure 2. Lignans from Styrax species 


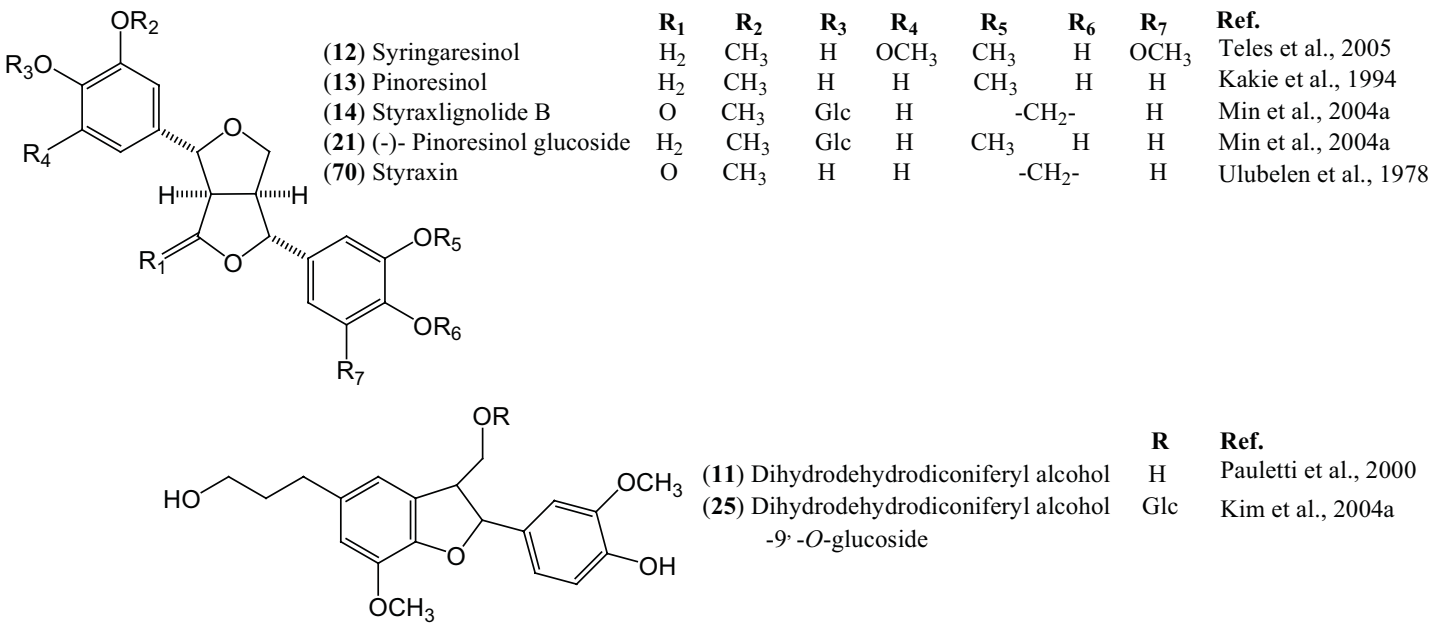

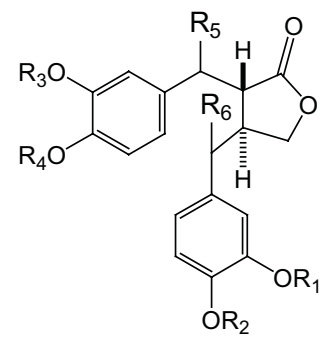

(15) Styraxlignoide C (16) Styraxlignoide D

(17) Styraxlignoide E

(18) Styraxlignoide F

(22) Styraxjaponoside A

(23) Styraxjaponoside B

$\begin{array}{lllllll}\mathbf{R}_{1} & \mathbf{R}_{\mathbf{2}} & \mathbf{R}_{\mathbf{3}} & \mathbf{R}_{\mathbf{4}} & \mathbf{R}_{\mathbf{5}} & \mathbf{R}_{\mathbf{6}} & \text { Ref. }\end{array}$

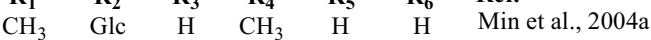

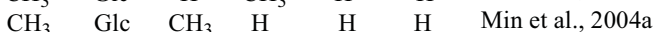

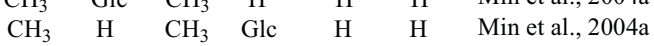

$\begin{array}{llllll}\mathrm{CH}_{3} & \mathrm{Glc} & \mathrm{CH}_{3} & \mathrm{CH}_{3} & \mathrm{H} & \mathrm{H}\end{array}$ Min et al., 2004a

$\mathrm{OR}_{2}$

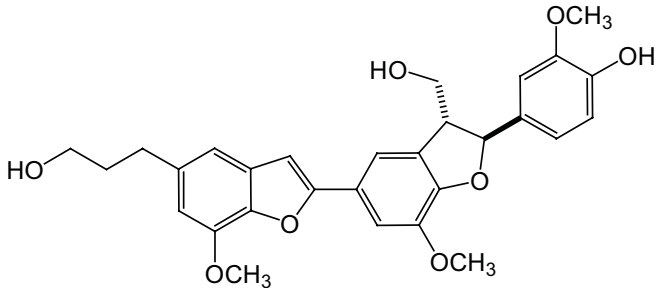

(31) Trans-5-(3"'-hydroxypropyl)-7-methoxy-2[2',3'-dihydro-3'-hydroxymethyl7'-methoxy-2'-(3"-methoxy-4"-hydroxyphenyl)- benzofuran-5'-yl] benzofuran

Ref.

Li et al., 2005<smiles>COc1cc(CC2CO[C@@H](c3ccc(O)c(OC)c3)[C@H]2CO)ccc1O</smiles><smiles>CCC(C)C(=O)OCCCc1cc(OC)c2c(c1)C1(c3ccc4c(c3)OCO4)OC21</smiles>

Figure 2. Contd.

Ref.

(72) 4-[3"-(1c-Methylbutanoyloxy)propyl]-2-methoxy(3',4'-methylenedioxyphenyl)-1a, 5b-dihydrobenzo- Akgul; Anil, 2003b $[3,4]$-cyclobutaoxirene

Ref.

(71) Lariciresinol Pauletti et al., 2002 


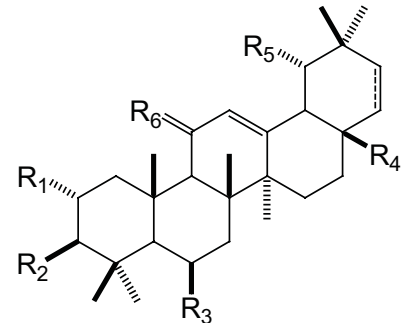

(32) Oleanolic aldehyde acetate (33) Erythrodiol-3-acetate $\mathrm{H}$ (35) Anhydrosophoradiol- $\quad \mathrm{H}$ 3-acetate

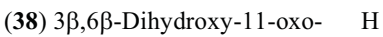
olean-12-en-28-oic acid

(40) $19 \alpha$-Hydroxy-3-oxo-olean- $\quad \mathrm{H}$

12-en-28-oic acid

(41) 6 $\beta$-Hydroxy-3-oxo-olean-

12-en-28-oic acid

(42) Sumaresinolic acid

(43) Siaresinolic acid

(44) Oleanolic acid

(73) Erythrodiol

(74) $3 \beta$-O-Trans- $p$-coumaroy

maslinic acid

$\mathrm{OH} O$-coumaroyl $\mathrm{H} \quad \mathrm{COOH}$
$R_{4} \quad R_{5}$

$\begin{array}{cccc}\mathbf{R}_{\mathbf{2}} & \mathbf{R}_{\mathbf{3}} & \mathbf{\mathbf { R } _ { \mathbf { 4 } }} & \mathbf{\mathbf { R } _ { 5 }} \\ \mathrm{OCOCH}_{3} & \mathrm{H} & \mathrm{CHO} & \\ \mathrm{OCOCH}_{3} & \mathrm{H} & \mathrm{CH}_{2} \mathrm{OH} & \mathrm{H} \\ \mathrm{OCOCH} & \mathrm{H} & \mathrm{CH}_{3} & \end{array}$

$\mathrm{H}_{2} \quad 21,22$ dihydro

$\mathrm{H}_{2} \quad 21,22$ dihydro

$\mathrm{H}_{2} \quad \triangle^{21}$

$\mathrm{OH} \quad \mathrm{OH}$

$\mathrm{COOH}$

$\mathrm{H}$

O 21,22 dihydro

$=\mathrm{O} \quad \mathrm{H} \quad \mathrm{COOH}$

$\mathrm{OH} \quad \mathrm{H}_{2} \quad 21,22$ dihydro

$\mathrm{COOH}$

$\mathrm{H}$

$\mathrm{H}_{2} \quad 21,22$ dihydro

$\mathrm{COOH}$

$\mathrm{COOH}$

$\mathrm{COOH}$

$\mathrm{H} \quad \mathrm{H}_{2} \quad 21,22$ dihydro

$\mathrm{OH} \quad \mathrm{H}_{2} \quad 21,22$ dihydro

$\begin{array}{lll}\mathrm{H} & \mathrm{H}_{2} & 21,22 \text { dihydro }\end{array}$

$\mathrm{CH}_{2} \mathrm{OH}$

$\begin{array}{ll}\mathrm{H}_{2} & 21,22 \text { dihydro } \\ \mathrm{H}_{2} & 21,22 \text { dihydro }\end{array}$
Ref.

Kim et al., 2004b

Kim et al., 2004b

Kim et al., 2004b

Wang et al., 2006a

Wang et al., 2006a

Wang et al., 2006a

Djerassi et al., 1955

Reynolds, 1982

Pauletti et al., 2000

Pauletti et al., 2002

$\mathrm{H} \quad \mathrm{H}_{2}$ 21,22 dihydro Pauletti et al., 2002

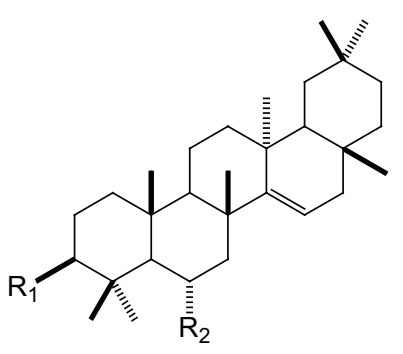

$\begin{array}{lll}\mathbf{R}_{1} & \mathbf{R}_{2} & \text { Ref. }\end{array}$

(19) Taraxerol $\quad \begin{array}{lrl}\mathbf{R}_{\mathbf{1}} & \mathbf{R}_{\mathbf{2}} & \mathbf{R e f} \\ \mathrm{H} & \text { Mim et al., 2004a }\end{array}$

(34) Euphorginol H OH Kin et al., 2004b

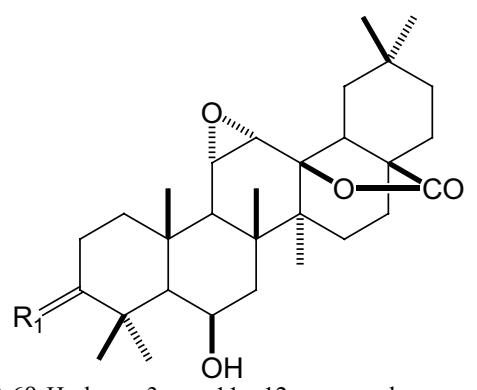

(37) $6 \beta$-Hydroxy-3-oxo-11 $\alpha, 12 \alpha$-epoxyolean-

$28,13 \beta$-olide (39)3 $\beta, 6 \beta$-Dihydroxy- $11 \alpha, 12 \alpha$-epoxyolean- $\quad \beta-\mathrm{OH}, \alpha-\mathrm{H}$ Wang et al., 2006a

$\begin{aligned} \mathbf{R}_{1} & \text { Ref. } \\ \text { O } & \text { Wang et al., 2006a }\end{aligned}$ $28,13 \beta$-olide

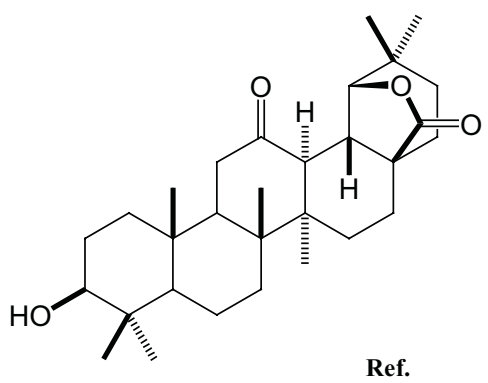

(36) $3 \beta$-Hydroxy-12-oxo-13H $\alpha$-olean- Wang et al., 2006a $28,19 \beta$-olide

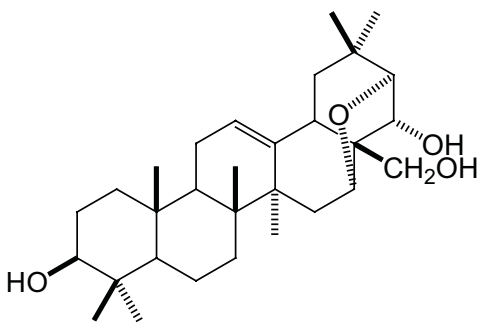

Ref.

(75) Jegosapogenol B Sugiyama et al., 1967a, b or Barringtogenol D

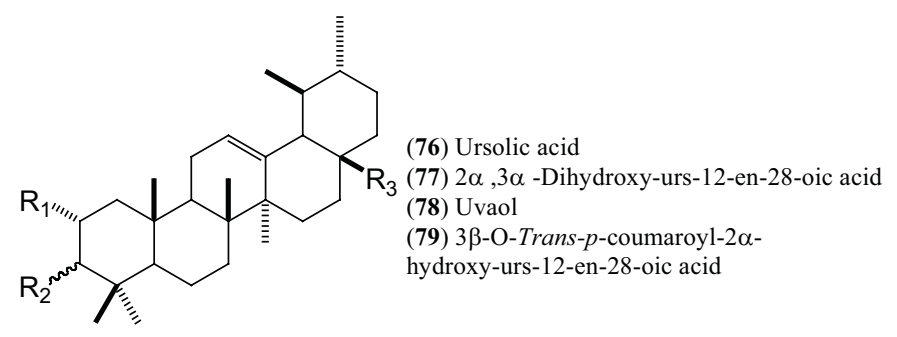

$\mathbf{R}_{1} \quad \mathbf{R}_{2}$

$\begin{array}{ll}\mathrm{H} & \beta-\mathrm{OH} \\ \mathrm{OH} & \alpha-\mathrm{OH}\end{array}$

$\alpha-\mathrm{OH}$

$\mathrm{OH} \quad \beta$-O-coumaroyl $\mathrm{COOH} \quad$ Pauletti et al., 2002

Figure 3. Triterpenes from Styrax species 
<smiles>COc1cc(/C=C/CO)cc(OC)c1OC</smiles>

(20) Syrigin
Ref.

Min B-S et al., 2004a<smiles>[R]C(=O)c1cc([R2])c([R])c([R3])c1[R]</smiles>

(80) Benzoic acid

(81) Vanilin

(82) $p$-Hydroxy benzaldehyde

(83) Vanilic acid

(84) Gallic acid

(85) Gentisic acid

(86) $p$-Hydroxy benzoic acid

$\begin{array}{clllll}\mathbf{R} & \mathbf{R}_{\mathbf{1}} & \mathbf{R}_{\mathbf{2}} & \mathbf{R}_{\mathbf{3}} & \mathbf{R}_{\mathbf{4}} & \text { Ref. } \\ \mathrm{OH} & \mathrm{H} & \mathrm{H} & \mathrm{H} & \mathrm{H} & \text { Schroeder, 1968 } \\ \mathrm{H} & \mathrm{OH} & \mathrm{OCH}_{3} & \mathrm{H} & \mathrm{H} & \text { Schroeder, 1968 } \\ \mathrm{H} & \mathrm{OH} & \mathrm{H} & \mathrm{H} & \mathrm{H} & \text { Pastorova et al., 1997 } \\ \mathrm{OH} & \mathrm{OH} & \mathrm{OCH}_{3} & \mathrm{H} & \mathrm{H} & \text { Pastorova et al., 1997 } \\ \mathrm{OH} & \mathrm{OH} & \mathrm{OH} & \mathrm{OH} & \mathrm{H} & \text { Proestos et al., 2006 } \\ \mathrm{OH} & \mathrm{H} & \mathrm{OH} & \mathrm{H} & \mathrm{OH} & \text { Proestos et al., 2006 } \\ \mathrm{OH} & \mathrm{OH} & \mathrm{H} & \mathrm{H} & \mathrm{H} & \text { Proestos et al., 2006 }\end{array}$<smiles>[R]C=Cc1ccc([R2])c([R])c1</smiles>

(87) Cinnamic acid

(88) Coniferyl alcohol

R

$\mathrm{CH}_{2} \mathrm{OH}$

$\begin{array}{lll}\mathbf{R}_{1} & \mathbf{R}_{\mathbf{2}} & \text { Ref. }\end{array}$

(89) p-Coumaryl alcohol $\mathrm{CH}_{2} \mathrm{OH}$

(90) Caffeic acid

$\mathrm{COOH}$

(91) $p$-Coumaric acid $\quad \mathrm{COOH}$

(92) Ferulic acid

$$
\begin{array}{cll}
\mathrm{H}_{\mathbf{1}} & \mathrm{H} & \text { Reinitzer, 1914 } \\
\mathrm{OCH}_{3} & \mathrm{OH} & \text { Pastorova et al., 1997 } \\
\mathrm{H} & \mathrm{OH} & \text { Pastorova et al., 1997 } \\
\mathrm{OH} & \mathrm{OH} & \text { Proestos et al., 2006 } \\
\mathrm{H} & \mathrm{OH} & \text { Proestos et al., 2006 } \\
\mathrm{OCH}_{3} & \mathrm{OH} & \text { Proestos et al., 2006 }
\end{array}
$$<smiles>[R]c1ccc(/C=C/COC(=O)c2ccccc2)cc1[R]</smiles>

$$
\begin{aligned}
& \begin{array}{llll} 
& \mathbf{R} & \mathbf{R}_{\mathbf{1}} & \text { Ref. } \\
\text { (93) Cinnamyl benzoate } & \mathrm{H} & \mathrm{H} & \text { Reinitzer, } 1914
\end{array} \\
& \text { (94) } p \text {-Coumaryl benzoate } \mathrm{OH} \quad \mathrm{H} \quad \text { Schroeder, } 1968 \\
& \text { (95) Coniferyl benzoate } \mathrm{OH} \quad \mathrm{OCH}_{3} \quad \text { Reinitzer, } 1914
\end{aligned}
$$

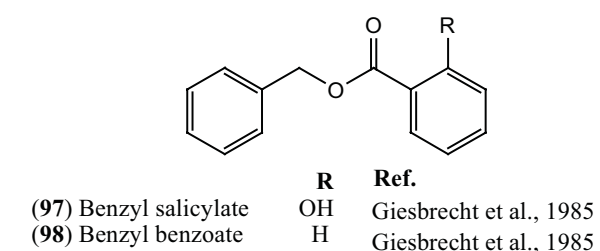

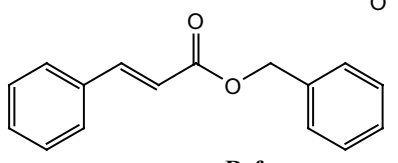

Ref.

(96) Benzyl cinnamate Pastorova et al., 1997<smiles>[R]c1ccc(/C=C/COC(=O)/C=C/c2ccccc2)cc1[R]</smiles>

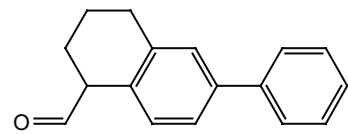

102) 6-Phenyl-tetrahydro-naphthaline $\mathrm{Re}$<smiles>COC(=O)C1CCC=C1C1CC(=O)O[C@@H]1c1ccc(O)c(OC)c1</smiles>

(104) Trans -(tetrahydro-2-(4-hydroxy-3methoxyphenyl)-5-oxofuran-3-yl)methyl benzoate Wang et al., 2006b
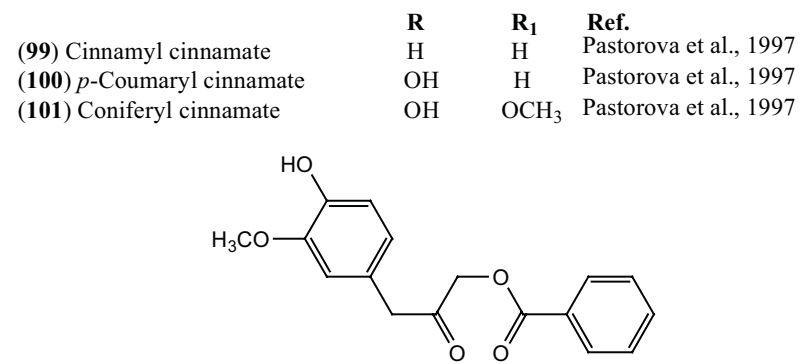

Ref.

(103)3-(4-Hydroxy-3-methoxyphenyl)- Wang et al., 2006b 2-oxopropyl benzoate

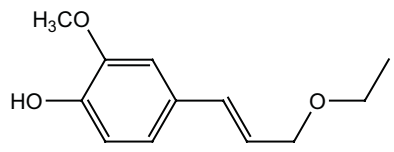

(105) 4-((E)-3-ethoxyprop-1-enyl)- Ref. 2-methoxyphenol<smiles></smiles>

$\begin{array}{ll} & \text { Ref. } \\ \text { (106) Quercetin } & \text { Proestos et al., } 2006\end{array}$<smiles>O=C1CC(c2ccc(O)cc2)Oc2cc(O)cc(O)c21</smiles>

Ref.

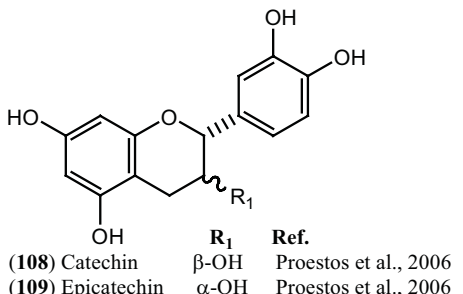

Figure 4. Phenolic compounds from Styrax species 

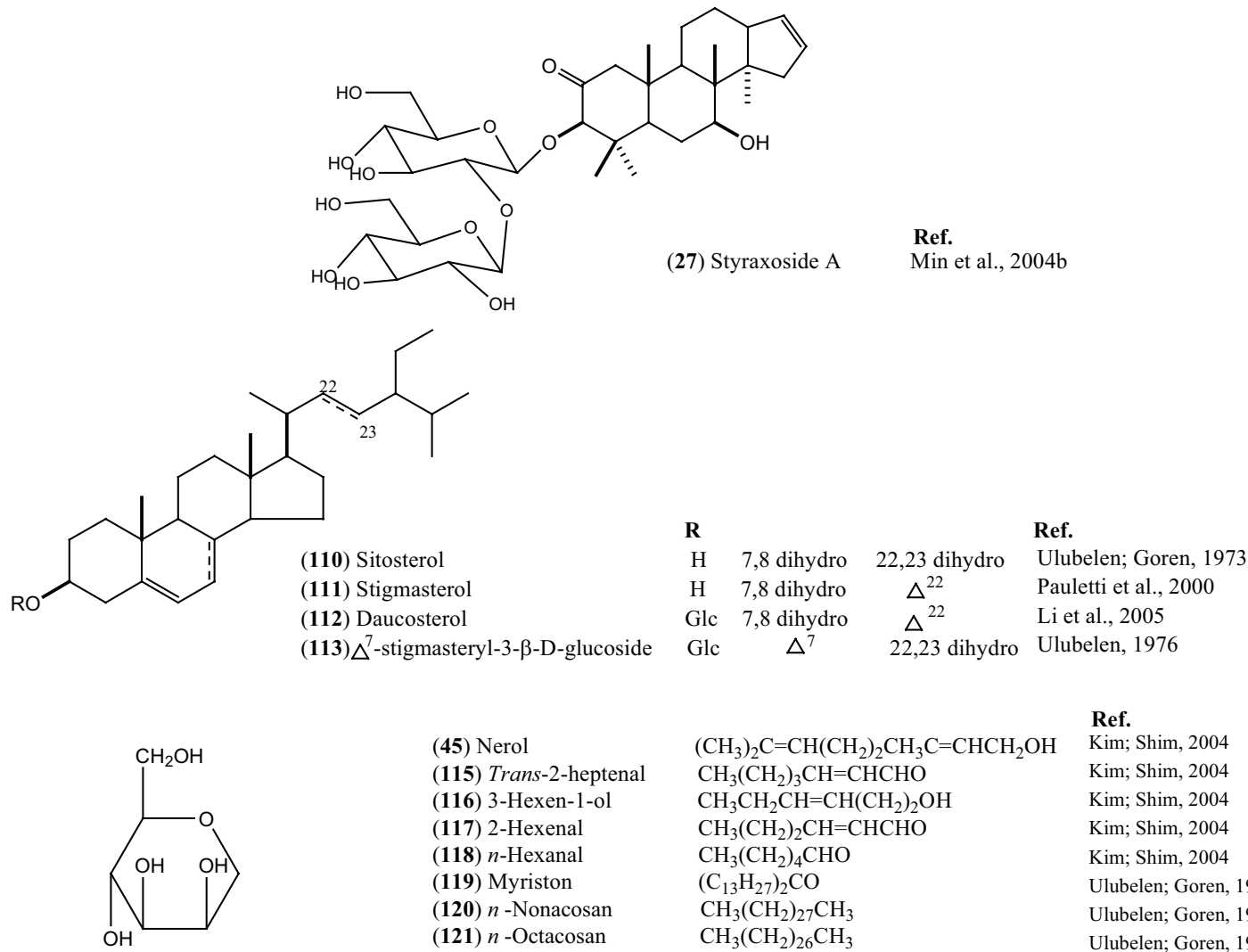

(45) Nerol

(115) Trans-2-heptenal

(116) 3-Hexen-1-ol

(117) 2-Hexena

(118) $n$-Hexanal

(119) Myriston

(120) $n$-Nonacosan

(121) $n$-Octacosan

(114) Styracitol or Styracite $\begin{aligned} & \text { Ref. } \\ & \text { Anil, } 1977\end{aligned}$

(122) Triacontanol

(123) Ginnon

(124) Stearic acid
(125) Oleic acid
(126) Linoleic acid
(127) Palmitic acid
(128) Lauric acid
(129) Arachidic acid
(130) Linolenic acid

$\mathrm{CH}_{3}\left(\mathrm{CH}_{2}\right)_{16} \mathrm{COOH}$

$\mathrm{CH}_{3}\left(\mathrm{CH}_{2}\right)_{7} \mathrm{CH}=\mathrm{CH}\left(\mathrm{CH}_{2}\right)_{7} \mathrm{COOH}$

$\left.\mathrm{CH}_{3}\right)_{2} \mathrm{C}=\mathrm{CH}\left(\mathrm{CH}_{2}\right)_{2} \mathrm{CH}_{3} \mathrm{C}=\mathrm{CHCH}_{2} \mathrm{OH}$

$\mathrm{CH}_{3}\left(\mathrm{CH}_{2}\right)_{3} \mathrm{CH}=\mathrm{CHCHO}$

$\mathrm{CH}_{3} \mathrm{CH}_{2} \mathrm{CH}=\mathrm{CH}\left(\mathrm{CH}_{2}\right)_{2} \mathrm{OH}$

$\mathrm{CH}_{3}\left(\mathrm{CH}_{2}\right)_{2} \mathrm{CH}=\mathrm{CHCHO}$

$\mathrm{CH}_{3}\left(\mathrm{CH}_{2}\right)_{4} \mathrm{CHO}$

$\left(\mathrm{C}_{13} \mathrm{H}_{27}\right)_{2} \mathrm{CO}$

$\mathrm{CH}_{3}\left(\mathrm{CH}_{2}\right)_{27} \mathrm{CH}_{3}$

$\mathrm{CH}_{3}\left(\mathrm{CH}_{2}\right)_{26} \mathrm{CH}_{3}$

$\mathrm{CH}_{3}\left(\mathrm{CH}_{2}\right)_{29} \mathrm{OH}$

$\left(\mathrm{C}_{14} \mathrm{H}_{29}\right)_{2} \mathrm{CO}$

Ref.

Kim; Shim, 2004

Kim; Shim, 2004

Kim; Shim, 2004

Kim; Shim, 2004

Kim; Shim, 2004

Ulubelen; Goren, 1973

Ulubelen; Goren, 1973

Ulubelen; Goren, 1973

Ulubelen; Goren, 1973

Ulubelen; Goren, 1973

Ref.

Breuer et al., 1987

Breuer et al., 1987

$\mathrm{CH}_{3}\left(\mathrm{CH}_{2}\right)_{4} \mathrm{CH}=\mathrm{CHCH}_{2} \mathrm{CH}=\mathrm{CH}\left(\mathrm{CH}_{2}\right)_{7} \mathrm{COOH}$ Breuer et al., 1987

$\mathrm{CH}_{3}\left(\mathrm{CH}_{2}\right)_{14} \mathrm{COOH} \quad$ Ulubelen et al., 1976

$\mathrm{CH}_{3}\left(\mathrm{CH}_{2}\right)_{10} \mathrm{COOH} \quad$ Ulubelen et al., 1976

$\mathrm{CH}_{3}\left(\mathrm{CH}_{2}\right)_{18} \mathrm{COOH} \quad$ Ulubelen et al., 1976

$\mathrm{CH}_{3}\left(\mathrm{CH}_{2} \mathrm{CH}=\mathrm{CH}\right)_{3}\left(\mathrm{CH}_{2}\right)_{7} \mathrm{COOH} \quad$ Ulubelen et al., 1976

Figure 5. Varius from Styrax species 